\title{
Yenidoğan Döneminde Akut Osteoartrit: Olgu Sunumu
}

\section{Acute Osteoarthritis in Newborn Period: Case Presentation}

\author{
Adil Umut Zübarioğlu1, Sinan Uslu1, Ali Bülbül1, Mesut Dursun1, Muhittin Çelik1, \\ Ebru Türkoğlu1, Nazan Dalgıç Karabulut2 \\ 1 Şişli Etfal Eğitim ve Araştırma Hastanesi, Yenidoğan Kliniği, Istanbul, Türkiye \\ 2Şişli Etfal Eğitim ve Araştırma Hastanesi, Çocuk Enfeksiyon Hastalıkları Kliniği, Istanbul, Türkiye
}

\begin{abstract}
ÖZET
Akut osteoartrit, kemik ve eklemin yenidoğan döneminde nadir görülen hematojen yaylımlı ciddi piyojenik enfeksiyonudur ve sıkılkla invazif girişimlere sekonder gelişmektedir. Yenidoğan döneminde bir çok hastalıkta olduğu gibi semptom ve bulguların nonspesifik olmasından dolayı tanısı zordur ve genellikle gecikir. Tanı ve tedavisi geciken vakalarda kalııı sakatıklara sebep olabilme potansiyeli olduğundan dolayı prognozu kötüdür. Bu olgu sunumunda omuz bölgesinde akut osteoartrit saptanan 15 günlük yenidoğan bebekte; hastalığın yenidoğan dönemindeki klinik, laboratuvar ve radyolojik özellikleri, güncel tanı ve tedavi yaklaşımları eşliğinde sunulmuştur. Yenidoğan döneminde yumuşak dokuda saptanan ödem ve hareket kısıtlılı̆ı, özellikle hastanede yatış anamnezi veren olgularda osteoartrit açısından ele alınarak değerlendirilmeli, hızlı ve etkin bir şekilde tedavi edilmelidir. Erken cerrahi drenaj ve etkene yönelik uygun antibiyoterapi ile sekel olasılığını minimale indirmeye çalışmak temel hedef olmalıdır. Bu hedefi gerçekleştirirken klinik yaklaşımın multidisipliner olması gereklidir. The Journal of Pediatric Research 2014;1(2):95-8 Anahtar Kelimeler: Yenidoğan, osteoartrit
\end{abstract}

\begin{abstract}
Acute osteoarthritis is a serious, hematogenously spread pyogenic infection of bone and joint which is rarely encountered in newborn period and often develops secondary to invasive procedures. As in many diseases seen in neonatal period, its diagnosis may be difficult and delayed because of nonspecific signs and symptoms. Poor prognosis is related to permanent sequelae in cases with delayed diagnosis and treatment. In this case report, 15 days old newborn with acute osteoarthritis on shoulder is presented with clinical, laboratory and radiologic features of the disease along with current diagnostic and therapeutic approaches. Soft tissue edema and movement restriction detected in neonatal period should be evaluated for osteoarthritis and treated quickly and effectively especially in patients with history of hospitalization. The main goal should be minimizing the possibility of sequelae with early surgical drainage and proper antibiotherapy against infectious agent with a multidisciplinary approach. The Journal of Pediatric Research 2014;1(2):95-8

Key Words: Newborn, osteoarthritis
\end{abstract}

\section{Giriş}

Akut osteomiyelit ve septik artrit, kemik ve eklemin yenidoğan döneminde nadir görülen (1000 yenidoğan yatışında 1-3 olguda) hematojen yayılımlı ciddi piyojenik enfeksiyonlarıdır (1). Yenidoğan ve erken bebeklik döneminde genellikle birlikte görüldüklerinden dolayı osteoartrit olarak tanımlanmakta ve sıklıkla invazif girişimlere sekonder gelişmektedirler.
Hastalığın klinik özellikleri, etken mikroorganizmalar ve prognozu daha büyük yaş gruplarından değişiklik göstermektedir. Yenidoğan döneminde bir çok hastalıkta olduğu gibi semptom ve bulguların silik ve nonspesifik olmasından dolayı tanısı zordur ve genellikle gecikir. Uygun zamanda tanı almayan ve tedavisi geciken vakalarda kalıcı sakatlıklara sebep olabilme potansiyeli olan bir hastalık olduğundan prognozu kötüdür $(2,3)$. Bu olgu sunumunda omuz bölgesinde akut osteoartrit (OA) saptanan 15 günlük 
yenidoğan, hastalığın yenidoğan dönemindeki klinik, laboratuar ve radyolojik özellikleri güncel tanı ve tedavi yaklaşımları eşliğinde irdelenmiştir.

\section{Olgu Sunumu}

Antenatal izlemlerinde herhangi bir sorunu olmayan, 21 yaşındaki annenin ilk gebeliğinden, zamanında, normal yolla ve 3200 gram ağırlığında doğan 15 günlük erkek bebeğin, postnatal ikinci gününde ateş ve huzursuzluk şikayeti ile başvurduğu hastanede dehidratasyon teşhisi ile takip ve tedavi edildiği öğrenildi. Taburcu olduktan dört gün sonra kolunda hareketsizlik fark edilen hasta polikliniğimize getirildi. Fizik muayenesinde genel durum orta, huzursuz görünümde olan hastanın sağ kolunda moro refleksi alınamıyordu ve sağ omuzda şişlik, ISı artışı ve eritem mevcuttu. Laboratuvar değerlendirmesinde lökosit sayısı:19100/mm³, C-Reaktif Protein (CRP):25,7 mg/dl, Eritrosit Sedimentasyon Hızı (ESH):68 mm/saat, periferik yaymada sola kayma saptandı. Hastanın düz omuz grafileri çekildi ve yumuşak dokuda hacim artışı saptandı. Ortopedi uzmanı tarafından omuz eklemine iğne ile ponksiyon yapıldı, pürülan mayii geldiği izlendi ve gram boyamada bol lökosit görüldü. Mevcut bulgularla septik artrit ön tanısı ile uygun dozlarda Vankomisin ve Meropenem tedavisi başlandı. Hastanın idrar, kan ve bos kültürleri alındı; üreme olmadı. Ortopedi uzmanı tarafından hastaya anestezi altında açık drenaj ile dekompresyon uygulandı. Hastanın sinovyal sıvı kültüründe Metisilin duyarlı Staphylococcus aureus saptandı. Çekilen ekstremite manyetik rezonans görüntülemesinde (MRG) omuz ekleminde lobulasyon gösteren yaygın efüzyon, subakromial bursit, sinovit, artrit ve humerus başında hafif deformasyon, epifiz hattında lizis, epifiz destrüksiyonu saptandı ve patolojik görünümler osteomiyelitle uyumlu bulundu (Resim 1, 2). Hastanın antibiyotik tedavisi, sinovyal sıvı kültüründe Metisilin duyarlı Staphylococcus aureus üremesi üzerine Çocuk Enfeksiyon Hastalıkları Uzmanı'na danışıldı. Çocuk Enfeksiyon Hastalıkları Uzmanı tarafından hastanın yenidoğan olması ve enfeksiyonun omuz bölgesi gibi sekel olasılığı yüksek bir alanda olması



Resim 1. Hastanın çekilen MRG'sinde sağ omuz bölgesinde ok ile gösterilen alanda yaygın efüzyon, artrit ve sinovit ile karakterize patolojik bulgular saptanmıştır nedeniyle Vankomisin ve Meropenem tedavisinde değişiklik uygun görülmedi ve tedavinin altı haftaya tamamlanması önerildi. Tedavi altı haftada sonlandırıldı ve hasta tam iyileşme ile taburcu edildi. Altı aylık kontrol muayenelerinde iskelet sistemi, nörolojik bulguları, büyüme ve gelişmesi normal saptandı.

\section{Tartışma}

Yenidoğan döneminde akut OA genellikle mikroorganizmanın kan akımı kaynaklı olarak kemik ve eklemlere yayılmasıyla oluşur. Bu yüzden risk faktörleri bakteriyemi oluşum riskiyle yakından ilişkilidir. Neonatal OA oluşumunda gebelik ve doğum eylemi ile ilişkili risk faktörleri olan prematürite, düşük doğum ağırlığı, asfiksi, bakteriyemi ve intravenöz veya umblikal kateter varlığı önde gelmektedir ve vakaların $1 / 3$ ile $1 / 2$ 'sinden sorumlu tutulmaktadır (4-6). Üç yüz vakalık neonatal OA derlemesinde, erkek cinsiyette 1,6 kat daha sık görüldüğü ve prematüre bebeklerde term bebeklere oranla daha fazla osteoartrit görüldüğü bildirilmiştir (7). Olgumuzun literatür verileriyle uyumlu olarak cinsiyeti erkekti ve hastanede yatışı sırasında intravenöz kateter takılarak tedavi edilmişti.

Yenidoğan döneminde klinik bulgular daha büyük yaş grubundaki vakalardan farklı özellikler gösterir. Bu farklıı̆ın sebebi kısmen yenidoğanların kemik kan akımının farklıı̆ına bağlanabilir. Neonatal dönemde metafizyel damarlar, epifizyel damarlar ile ossifikasyon çekirdeğinin kıkırdak prekörsüründe ilişki halindedir. Bu ilişki enfeksiyonun metafizden epifize hızla yayılmasına sebep olarak epifiz harabiyetine ve eklemin de tutulmasına neden olur. Bu durum yenidoğan döneminde artrit ve osteomiyelitin birlikte görülmesini açıklamaktadır (8). Vakamızda da osteomiyelit ve artrit birlikteliği gösterildiğinden olgu osteoartrit olarak tanımlanmıştır.

Nonspesifik semptomlar nedeniyle genellikle tanıs yenidoğan döneminde geciken ya da rutin radyografik incelemelerde şans eseri saptanan veya bölgede subkütan abse formasyonu oluşana kadar belli olmayan bir durumdur. Lokal bulgular hafif olabilir ve sistemik hiçbir bulgu olmayabilir,

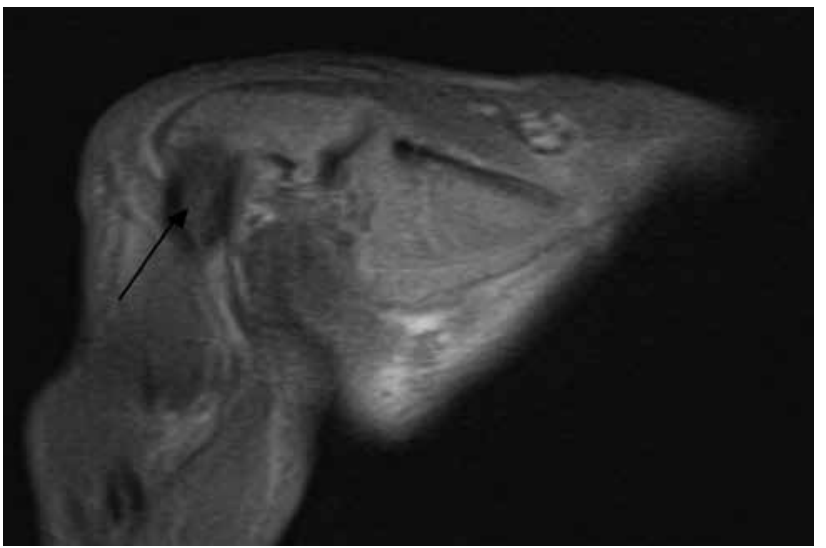

Resim 2. Hastanın çekilen MRG'sinde sağ omuz bölgesinde ok ile gösterilen alanda humerus başında hafif destrüksiyon ile karakterize patolojik bulgular saptanmıştır 
irritabilite tek şikayet olarak karşımıza çıkabilir (9-11). Klinik bulgulara göre 2 gruba ayrılır; birinci grup olan 'selim veya hafif form'da, bakteriyemi düşük seviyede veya geçici olup enfeksiyon belirtileri hafiftir veya lokal şişlik veya disabilite dışında yoktur. Semptomlar birkaç hafta içinde sona erer. Diğer grup olan 'şiddetli form'da ise uzamış veya ağır bakteriyemi sıktır ve sistemik enfeksiyon bulgularının ön planda olduğu akut tabloya çoklu eklem tutulumu eşlik eder (12). Literatürde selim seyirli formun daha sık görüldüğü belirtilmiştir. Soto ve ark.'nın yaptıkları çalışmada ağrı ve hareket kısıtııı̆ı en sık görülen klinik bulgulardır (sırasıyla \%90 ve \%96). Diğer lokal bulgulardan şişlik $\% 73$ ve eritem \%45 vakada görülmüştür. Ateş ise sadece \%50 vakada saptanmıştır (13). Olgumuzda başvuru sırasında huzursuzluk, hareket kısıtılığı, yumuşak doku şişliği ve eritem mevcuttu ancak ateş saptanmadı. Mevcut bulgular ve klinik izlem göz önüne alındığında olgumuzda saptanan OA 'selim veya hafif' form olarak tanımlandı.

Geniş olgu serilerini içeren çalışmalarda OA'nın yenidoğanlarda sıklıkla (\%70-\%80) alt ekstremitelerde prezente olduğu bildirilmektedir. Üst ekstremite tutulumu nadir olup (\%10-\%20) en sık tutulan bölge ise omuzdur. Diğer yaş gruplarından farklı olarak yenidoğanlarda çoklu kemik tutulumu daha sıktır $(12,14,15)$. Olgumuzda literatürde de nadir olarak tanımlanan omuz bölgesi etkilenmişti.

Neonatal OA tanısını doğrulamada düz grafiler halen en yararlı tanı aracıdır. Hastalığın 7.-10. gününde kemik yıkımının radyolojik bulguları ortaya çıkar. Kemik ve eklem enfeksiyonu tanısında ultrason kullanımı yaygınlaşmaya başlamıştır. Bilgisayarlı Tomografi (BT) ve MRG tetkikleri ise ileri tetkik olarak konvansiyonel tetkikler sonrası yapılmalıdır. Olgumuzda öncelikli olarak çekilen düz omuz grafisi yumuşak dokuda hacim artışı olarak değerlendirildi. Ancak mevcut bulguları ile OA düşünülen hastada ileri inceleme için MRG yapıldı. MRG'de omuz ekleminde artrit ve humerusta osteomiyelitle uyumlu patolojik bulgular saptandı.

Eklem alanını içeren enfeksiyonlarda, klinik ve radyolojik kanıtların olması iğne aspirasyonu ile tanının kesinleştirilmesini gerektirir. Literatürde eklem ve kandan mikroorganizma üretme oranı \%84 bulunmuştur (13). Çoğu olgunun oluşumu erken bakteriyemi sonrasında olduğundan OA etiyolojisinde rol oynayan etkenler neonatal sepsis etkenlerini yansıtır. Gram pozitif koklar \%85 ile en sık izole edilen mikroorganizmalardır. Aralarında en sık Staphylococcus aureus görülür. Streptococcus agalactia son yıllarda daha sık izole edilmeye başlanmıştır. Bu etkenin neden olduğu vakalar genellikle 3.-4. haftada ortaya çıkar ve hafif klinik bulgular gösterir. Gram negatif enterik basiller neonatal bakteriyemide sık etken olsa da OA etkeni olarak nadir etkenlerdir (16). Olgumuzdan ince iğne aspirasyonu ile aldığımız sinovyal SIVı kültüründe literatürle uyumlu olarak Metisilin duyarlı Staphylococcus aureus üredi.

Yenidoğan vakalarında başlanacak ampirik antibiyotik tedavisinde Metisilin rezistan Staphylococcus aureus etkeni göz önünde bulundurulmalıdır (17). Osteoartritin başarılı tedavi edilebilmesi için hızı klinik tanı yanında enfeksiyöz ajanın belirlenmesi gerekir. Tedavinin şekli ve süresi ile ilgili kontrollü çalışma bulunmamaktadır. Genel olarak önerilen antibiyotik tedavisinin parenteral yolla başlanarak 4-6 hafta süreyle uygulanmasıdır. Olgumuzda etken olarak Staphylococcus aureus üremesi olduğundan literatürde önerildiği gibi klinik yanıt aldıktan sonra tedavi 3 hafta daha devam edilip altı haftada sonlandırıldı (18).

Neonatal dönemde OA'ya bağlı mortalite düşüktür ve hastalığın şiddeti eşlik eden sepsis tablosuyla ilişkilidir. Ancak yapılan birçok çalışmada modern tedavi seçeneklerine rağmen OA'nın morbiditesi ve sekel oranlarının halen yüksek olduğu dikkati çekmektedir. Neonatal OA kalıcı eklem bozukluklarına, kıkırdaksı büyüme plağında hasara ve sekonder iskelet büyüme bozukluklarına (artrit, eklem hareket açıklığında azalma, ekstremite kısalığı ve yürüyüş anormallikleri) sebep olabilir. Bildirilen kalıcı sekel oranı \%6 ile \%50 arasında değişmektedir $(3,6)$. Vakalarda sekel olasıığı ile ilgili çok sayıda risk faktörü vardır. Bunlar tanıda ya da cerrahi drenajda gecikme, kalça veya omuz tutulumu, antimikrobiyal tedavinin kısa tutulması, seri ölçümlerde yüksek seyreden CRP ve ESH değerleri ve tedaviye klinik yanıtın yavaş olmasıdır $(19,20)$. Diğer çalışmalarda ise osteomiyelitle beraber Metisilin rezistan Staphylococcus aureus olmasının sekel riskini arttırdığı gösterilmiştir $(21,22)$. Bizim olgumuzda tutulan eklem omuz eklemi gibi sekel olasılığı yüksek bir bölge olmasına rağmen, erken cerrahi drenaj yapıp tedavimizi üreyen etkene göre uygun sürede yaptığımızdan dolayı hastamızın 6 aylık takiplerinde eklem hareket açıklığında kısıtııık veya ekstremite kısalığı gibi sekellere rastlamadığımızı düşünmekteyiz.

\section{Sonuç}

Yenidoğan döneminde OA erken tanısı, semptomların belirsiz ve nonspesifik olması nedeniyle güçtür. Hastamızda sağ kolda hareketsizlik ve omuzda minimal şişlik dışında bulgu yoktu. Yenidoğan döneminde yumuşak dokuda saptanan ödem ve hareket kısıtııı̆̆ı özellikle hastanede yatış anamnezi veren olgularda OA açısından ele alınarak değerlendirilmeli, hızı ve etkin bir şekilde tedavi edilmelidir. Direk grafiler ile görüntüleme yapılmalı ancak klinik şüphe halinde mutlaka BT ve MRG gibi ileri tetkikler yapılmalıdır. Erken cerrahi drenaj ve etkene yönelik uygun antibiyoterapi ile sekel olasılığını minimale indirmeye çalışmak temel hedef olmalıdır. $\mathrm{Bu}$ hedefi gerçekleştirirken klinik yaklaşımın multidisipliner olması ve ortopedi ve fizik tedavi uzmanları ile işbirliği içinde çalışmak önemlidir.

\section{Kaynaklar}

1. Goldmann D, Durbin W, Freeman J. Nosocomial infections in a neonatal intensive care unit. J Infect Dis 1981; 144: 449-59.

2. Bergdahl S, Ekengren K, Erriksson M. Neonatal hematogenous osteomyelitis: risk factors for long-term sequelae. J Pediatr Orthop 1985; 5: 564-82.

3. Williamson JB, Galasko CS, Robinson MJ. Outcome after acute osteomyelitis in preterm infants. Arch Dis Child 1990; 65: 1060-62.

4. Coto Cotallo GD, Solis Sanchez G, Crespo Hernandez M, Ramos Aparicio A, Bousono García C, Orejas R-Arango G. Neonatal osteomyelitis. Study of a series of 35 cases. An Esp Pediatr 1990; 33: 429-34. 
5. Frederiksen B, Christiansen $P_{1}$ Knudsen FU. Acute osteomyelitis and septic arthritis in the neonate, risk factors and outcome. Eur J Pediatr 1993; 152: 577-80.

6. Asmar B. Osteomyelitis in the neonate. Infect Dis Clin North Am 1992; 6: 117-32.

7. Fox L, Sprunt K. Neonatal osteomyelitis. Pediatrics 1978; 62 : 535-42.

8. Ogden J. Pediatric osteomyelitis and septic arthritis. The pathology of neonatal oseomyelitis. Yale J Biol Med 1979; 52: 423-48.

9. Wong $M$, Isaacs $D$, Howman- Giles R, Uren R. Clinical and diagnostic features of osteomyelitis occurring in the first three months of life. Pediatr Infect Dis J 1995; 14: 1047-53.

10. Sarlangue J, Castella C, Pontailler J, Chateil J. Neonatal infections of the bone and joints. Arch Pediatr 2007; 14: 1081012.

11. Dan M. Septic arthritis in young infants: clinical and microbiologic correlations and therapeutic implications. Rev Infect Dis 1984; 6: 147-55.

12. Overturf G, Marcy M. Bacterial Infections of the Bones and Joints. In: Remington $\mathrm{J}$ and Klein $\mathrm{J}$ editors. Infectious Diseases of the Fetus and Newborn Infant. Fifth edition 2001. WB Sounders. Chapter 23; 1019-103.

13. Berberian G, Firpo $V$, Soto A, Lopez Manan J, Torroija C, Castro G, Polanuer P, Espinola C, Pineiro JL, Rosanova MT. Osteoarthritis in the neonate: risk factors and outcome. Braz $\mathrm{J}$ Infect Dis 2010; 14: 413-18.

14. Al Saadi MM, Al Zamil FA, Bokhary NA, Al Shamsan LA, Al Alola SA, Al Eissa YS. Acute septic arthritis in children. Pediatr Int 2009; 51: 377-80.
15. Prober C. Clinical approach to the infected neonate. In: Long $\mathrm{S}$, Pickering L- Prober $\mathrm{C}$ editors. Principles and practice of pediatric infectious disease. II edition 2006. Chapter 97; 53342.

16. Dessi A, Crisafulli M, Accossu S, Setzu V, Fanos V. Osteoarticular infections in newborns: diagnosis and treatment. J Chemother 2008; 20: 542-50.

17. Korakaki E, Aligizakis A, Manoura A, Hatzidaki E, Saitakis E, Anatoliotaki M, Velivasakis E, Maraki S, Giannakopoulou C. Methicillin-resistant Staphylococus aureus osteomyelitis and septic arthritis in neonates: diagnosis and treatment. JPN J Infect Dis 2007; 60: 129-31.

18. Nelson JD. The bacterial etiology and antibiotic management of septic arthritis in infants and children. Pediatrics 1972; 50: 437-40.

19. Dagan R, Jacobs RF. Management of acute hematogenous osteomyelitis and septic arthritis in pediatric patient. Pediatr Infect Dis J 1995; 14: 40-4.

20. Bulbul A, Okan F, Yekeler E, Can E. Acute osteomyelitis of the iliac bone presenting with gluteal syndrome in a newborn. Eur J Pediatr 2009; 168: 1529-32.

21. Wang CL, Wang SM, Yang YJ, Tsai CH, Liu CC. Septic arthritis in children: relationship of causative pathogens, complications, and outcome. J Microbiol Immunol Infect 2003; 36: 41-6.

22. Narang A, Mukhopadhyay K, Kumar P, Bhakoo ON. Bone and joint infection in neonate. Indian J Pediatr 1998; 65: 461-4. 